\title{
Ideas, Ideology \& Intellectuals in Search of Russia's Political Future
}

\author{
Elena Chebankova
}

Abstract: The intellectual discourse of any state can function within two broad paradigms: consensual and pluralistic. In the first case, political elites, intellectuals, and the public agree on the base parameters of what constitutes "the good life" and argue about the methods of application. In the second case, participants hold radically different, incommensurable views, which coexist in society. This essay argues that the Western political system broadly rests on the politics of liberal consensus, formed throughout the period of capitalist modernization. But Russia's history took a different turn, following a path of alternative modernization. This engendered the politics of paradigmatic pluralism, in which a number of radically different politico-intellectual frameworks struggle for the dominant discourse. This essay examines these paradigms and argues that, due to the nature and substance of these models, fundamental change of Russia's dominant discourse, along with its main politico-institutional parameters, is unlikely.

ELENA CHEBANKOVA is Reader in Politics at the School of Social and Political Sciences at the University of Lincoln. She is the author of Civil Society in Putin's Russia (2013) and Russia's Federal Relations: Putin's Reforms and Management of the Regions (2009).
$\mathrm{R}$ through the politics of paradigmatic pluralism. More specific, two broad and radically different paradigms of "the good life" are present in Russia: pro-Western liberal and state-centered traditionalist. ${ }^{1}$ Their mutual questioning and criticism allow society to function within a relatively stable framework. While the two alternatives have struggled for discursive supremacy, the nativist and state-centered paradigm has emerged as a hegemonic discourse, with the support of the majority of the population. It is focused on avoiding shocks to the extant system and on sustaining sociopolitical stability. This essay demonstrates that the paradigmatic split in Russia has been historically determined. It continues with an examination of the main dimensions of Russia's hegemonic discourse, pointing to its general inclination toward national reconciliation and political stability. It then ponders the potential breakdown of the dichotomous nature of the existing ideological

(C) 2017 by the American Academy of Arts \& Sciences doi:10.1162/DAED_ 
Ideas, landscape and assesses the chances of a Ideology \& Intellectuals in Search of Russia's Political

Future

third, more radical alternative capturing the field. The essay concludes that, within the period under review, a fundamental change of the hegemonic paradigm in Russia is unlikely due to the dynamics of Russia's political system.

$\mathrm{U}_{\mathrm{n}}$ ntil very recent years, the Western political system has mainly rested on the politics of liberal consensus. This implies that society reaches a basic agreement on the idea of the good life within a liberal framework and hopes that there will be a gradual "step-by-step convergence of all values with liberal values."2 John Rawls called to establish a "base consensus" that would rest on liberal democratic, cultur$\mathrm{al}$, and political notions and act as a basic framework capable of encompassing diverging but "reasonable" ideas of the good life, thus buttressing pluralism of a liberal nature. ${ }^{3}$ This thinking has its origins in the monistic tradition of Plato and Aristotle that subsequently merged with monotheistic Christian conceptions to determine much of ensuing Western philosophy. 4

Critics of consensus politics represent a less practiced alternative that calls for the coexistence of incommensurable paradigms of the good life, their incessant dialogue, and mutual enrichment. This is the intellectual posterity of Thomas Hobbes, David Hume, and John Stuart Mill, advanced in the twentieth century by Isaiah Berlin, John Gray, Jean-François Lyotard, Shmuel Eisenstadt, Bernard Williams, and others. These critics point to the "absolutization" of liberalism by the proponents of liberal consensus politics and advocate the need to introduce meaningfully different alternatives that could enrich the cultural landscape of society. In short, consensus politics seek to operate within one broad politically liberal episteme that houses divergent ideas of an invariably liberal coloring. Pluralistic politics, in turn, have a number of epistemes that struggle to agree on the "base" positions, that propose meaningfully different ideas of sociopolitical development, and that compete for hegemony in the discursive realm.

A paradox of contemporary Russian politics is that, since the fall of the Soviet Union, it has rested on the pluralistic, rather than the consensus, model, with consequences for the country's intellectual landscape and potential for change to its extant regime. We shall address the participants in these debates as critical intelligentsia. To clarify positions at the outset, we will not limit our understanding of critical intelligentsia to those who are hopeful of altering Russia's extant political system. Rather, the discussion considers all those who ponder Russia's fate - her past, present, and future in its full complexity - as intellectuals. Hence, the account examines the full spectrum of existing opinion, regardless of its support or criticism of the existing political structure.

The two main paradigms of the good life - pro-Western liberal and state-centered traditionalist - struggle for position as Russia's hegemonic discourse. The first intellectual group, which includes some members of the government and financial elite, advocates the path of westernization for Russia. The second group adopts a conservative approach insisting on the creation of a strong state that relies on previous periods of Russia's history and her idiosyncratic political traditions. This paradigm has a pro-Western dimension, but it is a particular kind of westernization. It welcomes almost all aspects of Western modernity related to the capitalist economy, nation-state, religion, and family, but is skeptical about the West's postmodernist path. It also insists on Russia being Western and European but not subordinate to the West geopolitically. Although the pro-Western liberal paradigm is readily available in the current political climate in 
Russia, it functions merely as a discursive alternative, not as a meaningful option seriously considered by the majority of the population. Permanent dialogue between the two paradigms, as well as the fact that the traditionalist discourse already contains some elements of the Western system, stabilizes the traditionalist discourse and makes unexpected shifts in the country's political trajectory unlikely.

The paradigmatic split and the difficulties experienced by the pro-Western liberal paradigm are rooted in history; things become clearer if we sketch Russia's past three hundred years. First, Russia has a complex relationship with modernity, a social paradigm that largely lends a liberal consensus matrix to the politics of most Western European states. Russia is a second-wave modernization country, a circumstance that predetermines the paradigmatic split. Second, Russia's idiosyncratic relationship with modernity barred her from forming a clear civic identity supportive of liberal consensus politics. Finally, Russia's tumultuous twentieth century further contributed to the consolidation of the existing intellectual rift. Let me elaborate on these factors.

Russia's embrace of Western modernity was rather tardy. The Petrine period (16821721) was a watershed, during which Russia had only just launched a painful transformation toward modernity, met with resistance from a reluctant population. In contrast, most European countries had already experienced the Reformation and Enlightenment. Russia also lagged behind in industrialization. Western European countries underwent the peak of industrialization during the late eighteenth and most of the nineteenth centuries. Russia, in contrast, industrialized during the late Tsarist period and in the first half of the twentieth century, part of the Soviet "alternative modernity" paradigm.

In general terms, countries that experienced modernization in the second or third wave have faced the painful political consequences of ideological borrowElena ing. A borrowed idea can be "an asset to the development of a country and a reminder of its comparative backwardness, that is both a model to be emulated and a threat to national identity. What appears desirable from the standpoint of progress often appears dangerous to national independence."5 Hence, this cruel dilemma forces a split within the intellectual scene of second-wave industrialization states, of which Russia is part.

Intellectuals of those countries inevitably face an uneasy choice between losing intellectual and cultural independence by admitting their backwardness and adopting the externally borrowed progressive paradigm, or reaffirming nativism and tradition by holding on to the previously chosen path. The drama for Russian intellectuals is in the quandary of either adopting the ideology of individual freedom and bourgeois liberties, combined with embracing Western ontology, or clinging to the idiosyncratic centralized modes of governance that could conduct modernization and development, albeit in a risky alternative fashion. The latter option remains less explored, a problem that political scientist Alexander Dugin described as the need for the development merger between distinctively Russian epistemology and ontology. ${ }^{6}$

Further, Russia's complex experience with modernity impedes the process of forging a civic national identity, which also requires a bourgeois ideological consensus. Bourgeois elites that took the lead in creating the "imagined communities" of civic nation-states promoted the ideas of citizenship and society (Gesellschaft) at the expense of the traditional commune (Gemeinschaft); civil (economic), political, and social rights; individual liberty; civic responsibility; and representative democracy. These notions gradually formed the cornerstone of the liberal bourgeois 
Ideas, base consensus, upon which most modern Ideology \& Western European societies rest. Hence, Intellectuals in Search of Russia's Political Future

\section{ing political institutions. It also represents} the cardinal feature of modernity.

Russia's path of "alternative modernity," engendered by Soviet Communism, featured a different set of values. Bourgeois individual liberties were replaced by the supremacy of community over the individual, the idea of liberating masses of workers in order to dispense with exploitation and enable fairer participation in the life of the community. Equality was understood as social equality, which differed from the Western understanding of equality of opportunity. From this point of view, Russia's alternative modernity has not created a social fabric with an immanent understanding of civic identity and civic nation that rests on the notions of bourgeois individuality, liberal rights, and personal freedoms. This hinders a liberal base consensus and lends credence to the nativist state-centered discourse.

Therefore, while we can successfully identify the Russian state and Russian people, we struggle to pinpoint the dimensions of Russia's civic identity. ${ }^{7}$ It comes as no surprise that 43 percent of respondents to a 2011 VTsIOM (Russian Public Opinion Research Center) poll did not feel like part of the Russian nation and 20 percent could not understand the very idea of nation. Only 37 percent of respondents felt like part of the nation. ${ }^{8}$ Hence, in order to embrace a Western consensus matrix, Russia would first need to adopt a civic identity based on the ideas of individual liberty and a bourgeois nation-state. Russia would next need to embrace modernity's framework of capitalism and liberal base consensus, and then enter the era of postmodernity, with its global civil society and the gradual fading of national identity.
Finally, Russia's two major national catastrophes of the twentieth century exacerbate paradigmatic differences. The first state collapse followed Russia's entry to World War I, which resulted in the fall of the monarchy, disintegration of the empire, and subsequent (Bolshevik) October Revolution. The second major social catastrophe followed the fall of the Soviet Union. The demise of the erstwhile Soviet Empire completed the unfinished disintegration of the Russian Empire, the remains of which the Communists managed to reassemble in the course of the 1921-1923 Civil War. These two major events contributed to the significant dealignment of Russian and Soviet societies, involving transformations of all societal cleavages, as well as the reconsideration of all preexisting cultural codes and behavioral patterns. Twice in the twentieth century Russia experienced the breakdown of historic myths, demoralization of society, decline in interpersonal and institutional trust, and a significant drop in civic responsibility. The liberal paradigm presided over the March 1917 Romanov abdication, the February Revolution of 1917, and the 1991 disintegration of the USSR.

It has now become clear that Russia'sidiosyncratic relationship with modernity and the particularities of its twentieth-century history make the politics of paradigmatic pluralism almost inevitable. This predicament determines the nature of Russia's political discourse, both the hegemonic and the alternative. It is strategically important that Russia's elite allow a dialogue among the alternative discourses, while subtly marginalizing those that lie outside the state-endorsed dominant discourse. Moreover, the state does not try to reach a consensus between liberals and traditionalists, and thus fully embraces the existing divide within society. Various ideological alternatives appear on television, radio, and in print. Radical liberals, foreign journalists, and advocates of 1990s-style policy are 
daily participants in Russia's main political talk shows. Yet pro-state conservatives usually outnumber and dominate them.

Pro-Western liberal ideas therefore appear peripheral. They act as a reminder that radical alternatives are available and that such alternatives could pose a threat to the extant stability. Hence, high public awareness of the neoliberal paradigm precludes it from being novel to the Russian public. Moreover, despite the paradigmatic pluralism, the 2ooos saw the consolidation of a hegemonic discourse through a significant shift toward a political center. Having experienced the state collapse and the obliteration of preexisting values during the 1990s, contemporary Russians are reluctant to embark on radical vicissitudes. They lean toward socioeconomic stability at the expense of radical and, in particular, pro-Western liberal alternatives. This brings us to the nature of Russia's hegemonic discourse.

\section{$\mathrm{O}$} ne cardinal feature of this discourse, and a consequence of the immediate post-Soviet experience, is that it remains open to debate with its counterhegemonic competitors. With the fall of the USSR, a peculiar kaleidoscope of radically different ideas ranging from overtly pro-Western, Euro-Atlantic, socialist, liberal, neoliberal, liberal nationalist, civic nationalist, Stalinist, nostalgically Soviet, and even fascist emerged in Russia to fill the void of erstwhile Soviet uniformity. Economic depression, along with a wealth of opportunities for rapid enrichment, has become a milieu in which such styles, ideologies, and movements develop. The need to survive this radically pluralistic environment from both economic and sociopolitical perspectives taught Russians to be tolerant of paradigmatic differences. Hence, post-Soviet Russians emerged from the collapse of the USSR as pluralistic liberals who welcomed radically different alternatives.
Interestingly, intolerance of beliefs and political radicalism is often a feature of pro-Western radical liberal circles whose views unfortunately do not fit well with the inclinations of the majority. This often results in representatives of the liberal wing blaming ordinary people for self-imposed servility, a lack of civic consciousness, an absence of respect for liberal principles, and disdain for the countries that promote such values. ${ }^{9}$ It is also clear that the tactics of radicalizing the discourse impede the chances of a liberal project in Russia. Critics and sympathizers of the liberal cause often appeal to liberal public figures by asking them to reconsider their discursive practices. They implore them to abandon their Russophobia (or anthrophobia) that manifests in shocking journalistic expressions, as well as political profanations, aiming to strike at the heart of Russia's hegemonic discourse.

These voices - in particular Sergey Kurginyan, Alexander Prokhanov, and Zakhar Prilepin - advise liberals to center themselves on Russia, turn to defending the country's interests internationally, and abandon the unconditional support of global oligarchy. These critics argue that the failure of the liberal project and de-Sovietization of Russia occurred not because of the nature of the Soviet Union, but because it became clear that alternative policies involved the full-scale deconstruction of Russian society in the interests of Western powers. ${ }^{10}$ Simultaneously, critics invoke liberals to develop a Russia-centered liberal epistemology that could challenge the extant political system from all directions without engaging in the destructive practice of national self-denial.

Many moderate liberals accept the need to play down their discourse and narrow disagreements with traditionalists. Russia's great Western philosopher, Alexander Herzen, once emphasized his affinity with traditionalist Slavophiles: "Like Janus, 
Ideas, or a two-headed eagle, we looked in opIdeology \& Intellectuals in Search of Russia's Political

Future posite directions, but one heart beats in our breasts."11 But today, political scientist Sergey Stankevich regrets, "we have different hearts. It is our task to find ways in which we can rekindle our dialogue in a similar fashion to the dialogue between Westerners and Slavophiles in the 19th century." 12

Contemporary hegemonic discourse focuses on three notions: 1 ) the idea of state sovereignty; 2) the ideology of the multipolar world; and 3 ) the idea of national reconciliation. The multipolar world ideology bears the concept of state sovereignty at its heart. Hence, I will focus on the notion of state sovereignty and combine these points.

$\mathrm{O}$

ver the past decade, the concept of state sovereignty, seen by the capacity for political development free from external influence, has become the principal unifying factor in Russia. There this idea, much in the classical republican and neo-Roman fashion, invokes civic solidarity, patriotic awareness, and a sense of belonging. Hence, the notions of external freedom and territorial integrity are unconditional "red lines" that Russia's hegemonic discourse is unwilling to relinquish. Russian political scientist Viacheslav Nikonov argues that only two countries in Europe - Russia and England - enjoy over five hundred years of sovereign independent history. ${ }^{13}$ The red lines have been drawn largely by Russia's successful maintenance of its territory and ability to shape its future foreign and domestic policy over such a long period. Painful memories of occasional state collapses further consolidate the desire for sovereignty. Proponents of sovereignty use these examples to argue that grassroots movements would invariably emerge to restore national control over the state just as it happened during the Times of Trouble - the period between the end of the Rurik Dynasty in 1598 and the start of the Romanov Dynasty in 1613 - and at the end of the Russian Civil War. ${ }^{14}$

Further, the international atmosphere created by the fall of the USSR also raised debates about state sovereignty. With the collapse, the United States took steps that had the potential to shift the international relations structure toward unipolarity. These have included various "humanitarian interventions," "regime changes," and other initiatives used to consolidate America's global leadership. And while global institutional structures remained unchanged, these processes worried Russia's intellectuals and policy-makers. They pondered metaphysical issues invoking questions over international ethics and the direction in which the contemporary world order should evolve.

Russia's hegemonic discourse advocates a multiplicity of the world's political forms and states' entitlement to independent development. These ideas oppose the EuroAtlantic universalist logic of globalist democratization. Russia's minister of foreign affairs, Sergey Lavrov, argues that the ability of states to pursue political cultural distinctness remains the cornerstone of the world's lasting peace. In his September 2015 speech to the Russian State Duma, he advocated creating a more just, polycentric, and stable world order. He claimed that imposing a particular developmental recipe on weaker countries would increase chaos and be met with resistance by many states. ${ }^{15}$ Sergey Kurginyan concurs, arguing that many developing countries undergo the phase of incipient modernity (dogonyayushchii modern), which the postmodern West, through its foreign-policy actions, dismantles. With this in mind, desovereignization of formerly secular sovereign states in the Middle East triggers the desovereignization dynamic worldwide. This has the potential to result in a new "global disorder" that suits contemporary global capital. ${ }^{16}$ 
A search for national reconciliation is another cornerstone of the hegemonic discourse. It may become tempting to claim that the search for reconciliation would immediately imply a search for a "base consensus" and the desire to dispense with the politics of paradigmatic pluralism. While the construction of a base consensus could significantly overlap with the search for reconciliation, they still represent two qualitatively distinct categories. Reconciliation occurs when the two warring parties accept the existing divide and move forward on that assumption, meanwhile forgiving each other for transgressions that took place in the fight for prevalence. This does not involve forming consensus in ideological terms, which would invariably involve the prevalence of one ideological paradigm at the expense of another. Reconciliation is merely admitting that both sides have different opinions and that there are some issues that nevertheless unite them and help them move forward. Hence, they remain different albeit united on some consolidating grounds.

Those grounds need not be ideological. Proponents of reconciliation consciously avoid the push toward forming an ideological base consensus; neither side should dominate. In his November 4, 2015, speech to the Congress of Russia's Compatriots, Vladimir Putin insisted that the proposed reconciliation should not equate to uniformity in views, but rest on spiritual unity and a sense of belonging to one country united by common history and language. Indeed, history and attachment to a common homeland make people equal participants of the past glories of the nation and members of the same territorial community. There is always an appeal to civic loyalty and national unity in lieu of more divisive ideas such as language, ethnicity, religion, or the ideological treatment of particular elements of political structures. ${ }^{17}$
Hence, intellectuals and the general pub- Elena lic have formed a clear plan for reconciliation organized around the following points: First, they concur with an idea that contemporary Russia is a direct inheritor of the Soviet Union and that most achievements in the post-Soviet period stem from Soviet times. While the imperial and medieval eras made indispensable contributions to the development of the Russian state, it was the Soviet period that had a decisive impact on how contemporary Russia looks today. Achievements in science, technology, industry, medicine, and health care, the idea of victory in the Great Patriotic War - all derive from the USSR. As does Russia's current social divide between the wealthy and poor, a result of the privatization of Soviet industrial assets. The Soviet period also shapes contemporary Russian anthropology and Russia's collective unconscious. With the quest for consumption and a simultaneous idealistic vision of reality, Russians inherited most of their behavioral patterns from Soviet times. ${ }^{18}$

Second, the public must learn of the tragedies of the formative period of the Soviet state. This would require the publication of the real number of victims from the purges of 1921 to 1954. Speculation over the number of victims is unacceptable for both ethical and political reasons. This part of Russia's history must be accepted as a great tragedy and every person who suffered injustice must be vindicated. Nevertheless, society must not focus solely on tragic episodes but also admit positive aspects of the Soviet experience. Russian journalist Maxim Shevchenko has claimed:

The idiosyncrasy of the Russian Revolution lies in the fact that it socially elevated masses of Russian people who were previously considered mere building material for the good life of the few. This process encompassed almost everything: purges of innocent victims as well as great victories and genuine sacrifices of the Soviet people. One historical peri- 
Ideas, Ideology \& Intellectuals in Search of Russia's Political Future od contained polar phenomena: monstrous bureaucracy resting on the dominance of the Communist party and the possibility of creating a truly socialist people's governance. The Russian revolution gave people the chance to construct a qualitatively different idea of equality, and our contemporary principles and ethics are direct inheritors of those ideals. ${ }^{19}$

Third, the Russian experience of revolution and industrialization must be compared with similar experiences of revolution, civil war, and industrialization in other states. The French Revolution and Reign of Terror usually figure as benchmarks. Russian scholars and commentators, including Sergey Kurginyan, Vitaly Tretyakov, Natalya Narochnitskaya, and Peter Tolstoy, have argued that, despite tragic episodes, French people reconciled with the history of their revolution, ensuing terror, and the Napoleonic wars. These intellectuals also call for an examination of the history of revolution and civil war in China, Spain, and the United States. They conclude that civil wars, conservative reactions, and even terrors follow most revolutions and radical transformations worldwide.

This three-point reconciliation strategy reflects a deeply held suspicion that invalidating the Soviet experience could invalidate Russia's contemporary order and lead to the new redistribution of power and property or the territorial disintegration of the state. Many dominant-discourse thinkers argue that de-Sovietization would undo nearly a hundred years of the country's history and lead to the assumption that Russians are not capable of drafting the main structural, cultural, and ideological dimensions of their future. Hence, finding the right balance between admitting to the wrongs of the Soviet period and acknowledging its rights becomes paramount. Russian media carefully treads that line. On the one hand, it denounces Soviet purges in almost every political analysis program. On the other hand, it recognizes Soviet achievements in the spheres of science, medicine, education, and ideological influence on the outside world. More important, the increase in the Soviet component of the discourse does not undermine its westernization. Alexander Zinovyev, the late Russian philosopher and émigré of the Soviet era, observed this phenomenon as early as 2000 . He argued that a country like Russia would require a strong state with an almost Soviet-like bureaucracy to deal successfully with its challenges. At the same time, the construction of this new state bureaucracy would go hand in hand with increased westernization. ${ }^{20}$

Yet this westernization is of a particular kind. The postmodern ideological package promoted by Western powers mostly generates skepticism among ordinary Russians. Looking at the West, Russians lament the growing domination of global oligarchy, "humanitarian" interventions leading to socioeconomic catastrophes, the growing lack of tolerance toward alternative opinions dressed in political correctness, and the substitution of real debate with media simulacra. In this light, Maria Zakharova, the spokeswoman for the Russian Ministry of Foreign Affairs, claims that Russia does not reject but upholds Western values. Thus, in a contemporary world, Russians perceive that their nation has become the true defender of the ideals that erstwhile defined the period of Western liberal modernity. ${ }^{21}$
The he final question concerns the stability of the extant balance between the moderate statist and liberal paradigms. How durable is their symbiotic coexistence and what could a legitimacy crisis, induced by either seri- ous economic decline or a political succes- sion, lead to? Here we should consider an outcome in which a revanchist and radical- chauvinist force dominates the scene. 
Though unlikely now, such a scenario was not a distant possibility throughout the past decade. Indeed, a more nuanced approach to Russia's ideological landscape would allow the exploration of a third, albeit minor, option. This discursive paradigm is often referred to as "political nationalism" or the "third force." ${ }^{22}$ It is focused on a radical agenda of repudiating external and internal enemies and advancing a project of "greater Russia." This force comprises diverging trends with wide-ranging ideological positions. Yet its representatives usually acknowledge Russia's discursive division of liberals and statist patriots and blame the Kremlin for being indecisive in repudiating the liberals.

They invoke the fate of Viktor Yanukovich, ex-president of Ukraine, who simultaneously pursued European-integration and politicoeconomic ties with Russia. This inconsistency, advocates of the third paradigm argue, ultimately led to Yanukovich's demise, and the Kremlin's inconsistency toward domestic liberals and the West could result in Russia's own liberal maidan revolution. ${ }^{23}$ These ideologists claim that the Kremlin must steer toward a "patriotic" trajectory and abandon futile attempts to reach a dialogic balance with the liberals. ${ }^{24}$ It is unacceptable, they claim, both that the statists' discourse contains substantial chunks of liberalism and that Russia's main media channels and state socioeconomic policies advance these positions. Russia, in their view, must adopt a steady line toward the national revival and cease "appeasing" the West by openly declaring it as an existential enemy rather than a dialogical partner.

Initially, such a radical approach may seem marginal. However, many observers claim that large segments of Russia's financial, political, and special services elite - who come across as liberal or conservative in public - had shared in this ideology in private, at least until the Crimean and Donbas events. ${ }^{25}$ In the aftermath of the 2005 Ukrainian Orange Revolution, it does not come as a surprise that the Kremlin viewed the nationalists as a tactical ally that could stabilize the extant political system and defend it from external interference. Therefore, this third cohort is substantial, uniting members of patriotic, liberal, monarchical, and even fascist opposition. As a political force, nationalists divided into two separate categories. The first group expected the restoration of the Russian Empire and advocated territorial expansion. The second wished for the creation of an ethnic Russian state and envisaged sacrificing some of Russia's ethnic territories in order to see this goal through.

However, this once-promising third force, buttressed by the silent support of financial elites and special services, gradually began losing its discursive niche. Some analysts claim that by 2016 , nationalists had become so marginalized and fragmented that they could not meaningfully discuss participation in the forthcoming parliamentary or regional elections. ${ }^{26}$ The emerging rift with the Kremlin, disagreements with the liberals, and the Crimean crisis all helped alter the discursive scene in Russia. As for the Kremlin, it subsequently sensed the danger associated with flirting with nationalists. The apparent failure of nationalists to protest against the West and their preoccupation with internal immigration indicated that, instead of protecting Russia's political regime from Western interference, this radical force had the potential to turn its guns against the Kremlin itself. The first signs of rupture between the Kremlin and nationalists took place in 2007-2008, when the state adopted a range of punitive measures against ethnic hatred and extremism. The immigration process was systematized, the judicial review for racial crimes was revised, and the dissemination of xenophobic literature was restricted. Political 
Ideas, nationalists then fully emerged as a radiIdeology \& Intellectuals in Search of Russia's Political Future front against the statists. This would have granted them an opportunity to survive as a meaningful discursive paradigm. It does not come as a surprise that during the December 2011 protests, liberals worked with nationalists and formed a single anti-Kremlin front. The nationalist cohort hoped to capitalize on the shortcomings of the Kremlin's policies in the international arena as well as on the state's inability to tackle corruption and the economic crisis. Nationalists promoted two broad agendas that the liberal cohort has generally approved. The first agenda focused on the relationship between Central Russia and the North Caucasus and advanced the Stop Feeding the Caucasus campaign, which sought to end Russian federal government spending on the region. The second agenda item was the general anti-immigration campaign geared toward the introduction of the visa regime with the Central Asian republics.

However, the events in Crimea and Donbas turned the tables radically, virtually obliterating this third discourse. Many nationalists initially supported the 2014 Maidan Revolution, attracted by the fact that their Ukrainian equals played a decisive role in the change of the Ukrainian political regime. Yet they quickly faced disappointment, given that the Ukrainian Revolution took on an anti-Russian ideological coloring. ${ }^{27}$ The subsequent outbreak of the bloody conflict in Donbas led these nationalists to adopt a radically pro-Russian agenda, arguing in favor of Russia's direct military involvement in rescuing the "Russian world" in Eastern Ukraine. This policy, however, resulted in further disappointment, for the mobilization potential of Russian nationalists was minimal and they were not able to attract a substantial number of volunteers who would agree to take up arms for this cause. ${ }^{28}$ This was mainly linked to the fact that Russia's general public was not in favor of the country's direct military involvement in the conflict and wished only to support the Russian population in Eastern Ukraine rhetorically. This led to a significant narrowing of the discursive niche in which nationalists could engage.

Further, the political field previously occupied by the revanchist ideologists has been gradually taken over by moderate liberals and statists. Following the failure of the December 2011 protests, moderate liberals began appealing to values with social currency, praising patriotism, proclaiming their "love of the motherland," and supporting development of the welfare state. This trend deepened in the wake of events in Crimea. The overwhelming majority of Russians backed the Kremlin and by doing so squeezed the liberal support base. This partly made the liberals accept the advice of their statist opponents to soften their stance toward the "people." The statists also intensified their patriotic rhetoric, seeing it as a useful tactical instrument in the struggle for the dominant discourse. Russian political scientist Sergey Karaganov has argued that contemporary Russia remained a nonideological state, thus adhering to our initial proposition of paradigmatic pluralism. Yet Russia obtained, Karaganov continued, the two consolidating ideas of sovereignty and defense, which united under the overarching notion of "patriotism." 29 This deprived nationalists of their habitual playground.

The fragmentation and weakness of the potential third force was demonstrated by its proponents' most recent attempt to set aside internal ideological differences and unite into a single group. The $25 \mathrm{Jan}$ uary Committee, established in 2016, represents a union of extremely diverse and largely incompatible forces. It includes 
monarchists led by Igor Strelkov, radical national democrats represented by Konstantin Krylov, National Bolsheviks led by Eduard Limonov, ultra-nationalist fascists such as Egor Prosvirnin, and oppositionist former security service officers such as Anatoly Nesmiyan. This ideologically diverse group supports irredentist claims of ethnic Russians in the post-Soviet space and the idea of establishing an ethnic Russian state based on the principles of justice, legality, and equality.

Members of the Committee are driven by their mutual detest of liberalism and the West and the search for internal enemies within the Russian state apparatus. The slide of Russia's third discourse, from a formerly promising political force to a marginalized group of intellectuals with dubious goals, is perhaps unfortunate for those who wished to create a sustainable political paradigm within this field and move it in a moderate direction. Yet their current political weakness suggests that the arrival of representatives of this paradigm in the highest echelons of Russia's power is unlikely, even within the conditions of economic and political crisis.

\begin{abstract}
A radical change that could fundamentally alter the political situation in Russia seems an unlikely prospect. Extraordinary as it may seem, at this point, Russia has run out of revolutionaries. First, contemporary Russia functions within the conditions of a paradigmatic pluralism that makes a vast number of options readily available. The presence of different paradigms in the mass media and public debate precludes the situation, in which a system-deposing paradigm could arrive unexpectedly, appearing more just and novel, and radically changing the hegemonic discourse. Despite the wealth of different paradigms, the state-centered conservative episteme won the hegemonic discourse; the majority of Russia's population and her
\end{abstract}

intellectuals support it. The main stabilizing feature of this discourse is that it does not seek ideological uniformity and welcomes various alternatives within the debate on domestic politics. It has little appeal to values and seeks national reconciliation. This discourse is also foreign-policy centered and, for that reason, has an overall consolidating effect. In addition, it is more open to debate than its liberal counterpart, which is often intolerant of nonliberal (but not illiberal) alternatives. Indeed, pro-Western liberals subconsciously feel that their paradigm may prevail only through the full and radical recasting of public consciousness that cannot take place overnight or even within a short period.

To realign the system fundamentally, one would need to dispense with the politics of paradigmatic pluralism and instill a new consensus, which could only be achieved via authoritarian means and would go against the grain of popular wishes. Considering the decisive liberal turn, those who anticipate that a changing regime in Russia would bear fruit and move the country in the direction of full integration into the Euro-Atlantic community overlook the fact that such a change could only be temporary. For this development to take full effect and result in a fundamental change, Russia would need the necessary conditions to form the liberal base consensus and move away from the politics of paradigmatic pluralism. This can only take place gradually through progressive accumulation of liberal capitalist behavioral patterns, a few generations of steady development in the modernist fashion, and the construction of the main dimensions of Russia's civic nation. The fifteen years phase pondered in this volume thus does not allow sufficient time for a fundamental change of this magnitude. 
Ideas,

Ideology \&

Intellectuals

in Search

of Russia's

Political

Future

${ }^{1}$ In philosophical terms, such paradigms of the "good life" can be seen through the Aristotelian lenses of spiritual, virtuous, and prudent politics that can ensure welfare and flourishing for humans.

2 Stuart Hampshire, "Justice is Strife," Proceedings and Addresses of the American Philosophical Association 65 (3) (1991): $24-25$.

3 John Rawls, Political Liberalism (New York: Columbia University Press, 1993).

4 John Gray, Berlin (London: Fontana Press, 1995); and Bernard Williams, In the Beginning was the Deed: Realism and Moralism in the Political Argument (Princeton, N.J. : Princeton University Press, 2005).

5 Reinhard Bendix, Embattled Reason: Essays on Social Knowledge (Oxford: Oxford University Press, 1979), 352.

${ }^{6}$ Alexander Dugin, "Rossiiskaia Identichnist v Sovremennom Mire," lecture at the Ural Polytechnic University, 2012.

7 Ibid.

${ }^{8}$ Otkrytaya Studia with Nika Strizhak, “Kto my: Russkie ili Rossiyane?” March 21, 2012, available at https://www.youtube.com/watch?v=CmlspuJ5AU8 (accessed January 17, 2017).

9 Vadim Slutsky, “Proryv Gnoinika,” Ekho Moskvy, March 6, 2014, http ://echo.msk.ru/blog/ vadimslutsky/1273246-echo/.

10 Paul Rodkin, "Pochemu Desovetizatsiya Dala Obratnyi Effekt," RIA Novosti, May 21, 2015, http ://ria.ru/zinoviev_club/20150521/1065729530.html.

${ }^{11}$ Bendix, Embattled Reason, 352.

${ }^{12}$ Duel with Vladimir Solovyev, "Kurginyan vs Nadezhdin," available at https ://www.youtube .com/watch?v=QE1Na64gQ8U (accessed November 17, 2015).

13 Pravo Znat! "Vyacheslav Nikonov," November 7, 2015, available at https ://www.youtube.com/ watch ?v=4j64b91T4ss (accessed November 12, 2015).

14 Duel with Vladimir Solovyev, "Kurginyan vs Nadezhdin."

15 "Vystuplenie Lavrova v Gosdume," https ://russian.rt.com/article/123511, October 14, 2015.

16 Spetsialnyi Korrespondent, September 29, 2015, available at https://www.youtube.com/ watch? v=l6I5cZD4Eyw (accessed January 3, 2017); and "Kurginyan : SShA - Novyi Karfagen, Ustraivayushchii Khaos po Vsemu Miru," Regnum, September 30, 2015, http://regnum.ru/ news/polit/1982223.html.

17 Bendix, Embattled Reason, 353.

18 Tochka Zrenia, "Velikiy Oktyabr i Sovremennost," November 7, 2015, available at https ://www .youtube.com/watch?v=lXLLBYqMvRM (accessed January 3, 2017).

19 Ibid.

${ }^{20}$ Rodkin, "Pochemu Desovetizatsiya Dala Obratnyi Effekt.” A number of Russian intellectuals note that Vladimir Putin and his elite are pro-Western, with Sergey Kurginyan branding Putin as a liberal statesman.

${ }^{21}$ Spetsialnyi Korrespondent, September 29, 2015.

22 Valery Solovey, "Bol', Gnev i Nenavist. Tri Uroka Russikim Natsionalistam iz Ukrainskogo Krizisa,” Slon, March 21, 2016, https://slon.ru/posts/65611.

23 Igor Strelkov, “Dlia Spaseniya Rossii My Sozdaem Tretyu Silu,” Dvizhenie Novorossiya, January 31, 2016, http://novorossia.pro/strelkov/1552-igor-strelkov-dlya-spaseniya-rossii-my-sozdaem -tretyu-silu.html; and Igor Strelkov, "My Protivostoim Liberalnomu Revanshu," Kolokol Rossii, 
January 29, 2016, http ://kolokolrussia.ru/russkiy-mir/igor-strelkov-m-protivostoim-liberalnomu Elena -revanshu?_utl_t=fb\#.

${ }^{24}$ Eduard Limonov, "Prizrak, Brodivshii po Rossii Materializovalsia," Svobodnaya Pressa, February 4, 2016, available at http://svpressa.ru/politic/article/141645/ (accessed January 16, 2017).

25 Solovey, "Bol', Gnev i Nenavist”; and Sut Igry, "Khvatit Kormit Kavkaz: Sergey Kurginyan ob Etoi Idee,” 2011, available at https ://www.youtube.com/watch?v=tUfBSi86Xa4 (accessed April 1, 2016).

${ }^{26}$ Solovey, "Bol', Gnev i Nenavist."

27 Limonov, "Prizrak, Brodivshii po Rossii Materializovalsia."

${ }^{28}$ Solovey, "Bol', Gnev i Nenavist."

29 Sergei Karaganov, "Mir Nakhoditisya v Predvoennom Sostoyanii,” Rossiya v Globalnoi Politike, February 17, 2016, http://www.globalaffairs.ru/pubcol/Mir-nakhoditsya-v-predvoennom -sostoyanii-17999. 